\title{
RETRACTION: Innovation Integrated Village Development Korea-Indonesia Partnership Model, Sukabumi District
}

\author{
Septiana Dwi Putrianti* \\ Postgraduate Program, National Institute of Public Administration (NIPA) \\ Polytechnic STIA LAN \\ Bandung, Indonesia \\ *septiana.dwiputrianti@poltek.stialanbandung.ac.id
}

The Editors and Publisher would like to indicate that data in this article (https://doi.org/ 10.2991/assehr.k.210629.032) has been used without authorization. This issue was reported by the article's author. As a member of the Committee on Publication Ethics (COPE), we followed COPE-compliant guidelines while investigating the case. Based on this it was concluded that this article should be retracted. Exceptionally, the original article was removed from our platform, given the potential negative impact on several partners and apparent infringement of other stakeholders' legal rights.

All parties would like to apologize for this error.

The full Atlantis Press Policy on Article Retraction can be found at: https://www.atlantispress.com/policies/article-retraction-and-withdrawal. 